\title{
ИСТОРИЧЕСКИЕ АСПЕКТЫ РАЗВИТИЯ МЕЛИОРАЦИИ ЗЕМЕЛЬ В ЗАПАДНОЙ СИБИРИ
}

\author{
() 2021 М.Т. Устинов, Д.А. Гаврилов ${ }^{(\mathbb{D})}$, Н.В. Елизаров \\ ФГБУН Институт почвоведения и агрохимии СО РАН, проспект Академика Лаврентьева, 8/2, \\ 2. Новосибирск, 630090, Россия. E-mail: ustinov@issa-siberia.ru
}

Приведен исторический обзор научно-практических материалов по разработке проектов мелиорации почв Запанной Сибири, показана необходимость их глубокого научного сопровождения. Рассматриваются методь и способы обоснования проектов мелиорации территории, разработанные коллективами исследователей различных специальностей: Института почвоведения и агрохимии СО РАН (СО АН СССР), Почвенного института им. В.В. Докучаева, Всероссийского научно-исследовательского института гидротехники и мелиорации (ВНИИГиМ) им. $А$. $Н$. Костякова.

Ключевые слова: мелиорация; Западная Сибирь; почвенно-мелиоративная карта; мелиоративные мероприятия.

Цитирование: Устинов М.Т., Гаврилов Д.А., Елизаров Н.В. Исторические аспекты развития мелиорации земель в Западной Сибири // Почвы и окружающая среда. 2021. Том 4. №2. e143. doi: 10.31251/pos.v4i2.143

На Всероссийском съезде сельских хозяйств, состоявшемся в Москве 10-20 декабря 1895 г. под покровительством Великого князя Сергея Александровича Романова, было принято решение об организации в Западной Сибири Барабинской сельскохозяйственной опытной станции. Однако едва начавшиеся мелиоративные работы в Барабе были приостановлены из-за Первой мировой войны и последовавшей Октябрьской революции (Маслов, 2005). Только в 1929 г. появилось первое научное учреждение по мелиорации земель Сибири - Убинская опытно-мелиоративная станция, расположенная в 1,5 км от железной дороги у истоков крупного Карапузского канала, построенного экспедицией И.И. Жилинского (рис. 1).

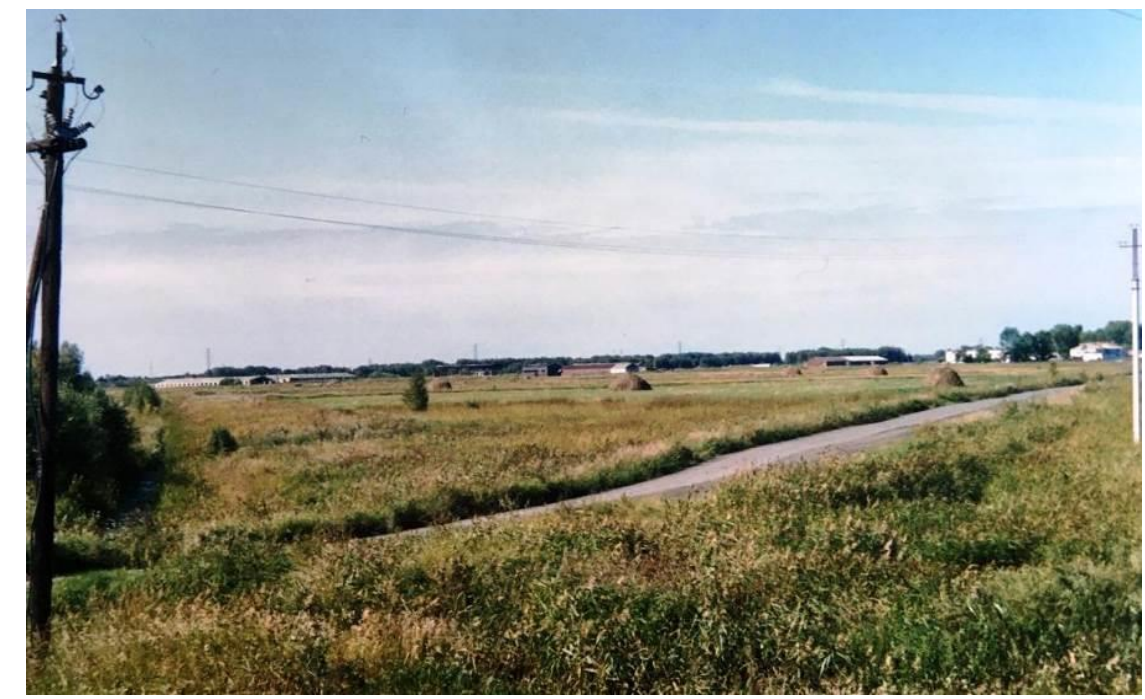

Рисунок 1. Карапузский магистральный канал (слева). Убинская опытно-мелиоративная станция (справа). Типовое опытное поле Убинской ОМС (центр фотографии). Дата 31.08.2002 г.

Из-за сложившегося комплекса природных условий Западная Сибирь представляет собой крайне сложный район, требующий научно обоснованных мелиоративных мероприятий по повышению и стабилизации плодородия почв. В противном случае возрастает риск развития негативных и даже деградационных процессов: прогрессирующего заболачивания и вторичного засоления в результате подъема минерализованных грунтовых вод. Природно-мелиоративные 
условия почвообразования в регионе имеют циклично-пульсирующий характер с чередующимися фазами обводнения и аридизации, обусловливающими процессы засоления и рассоления почвенного профиля.

Естественная дренированность Западно-Сибирской равнины различна, но Барабинская и Кулундинская низменности относятся к слабодренированным территориям. Глубина залегания первого от поверхности водоупора здесь сравнительно невелика (до 5-20 м), надводоупорные толщи обладают пёстрым сложением и обводнённостью. При общем равнинном рельефе ландшафт имеет сложное строение - чередование грив и межгривных понижений, заболоченных и озерно-болотных выровненных территорий.

Очень сложная палеогеографическая история Западно-Сибирской равнины, пестрота и засоленность материнских пород, неодинаковый уровень залегания и минерализация грунтовых вод в сочетании с чередующимися циклами обводненности и аридизации определили формирование очень сложного почвенного покрова. Автоморфные почвы разбросаны небольшими контурами по вершинам грив среди преобладающих полугидроморфных и гидроморфных почв, в различной степени засоленных или заболоченных. Широко распространенные гидроморфные и полугидроморфные засоленные почвы часто находятся в различных стадиях остепнения и трансформируются в автоморфные незасоленные. Диагностируются черноземы, сохранившие черты, присущие гидроморфным почвам, такие как остаточная солонцеватость, засоленность, реликтовое осолодение и аллювиальные горизонты. Геохимический состав почвообразующих пород и почв очень сложен, а наличие бессточных областей обусловливает перераспределение и аккумуляцию солей внутри территории (рис. 2).

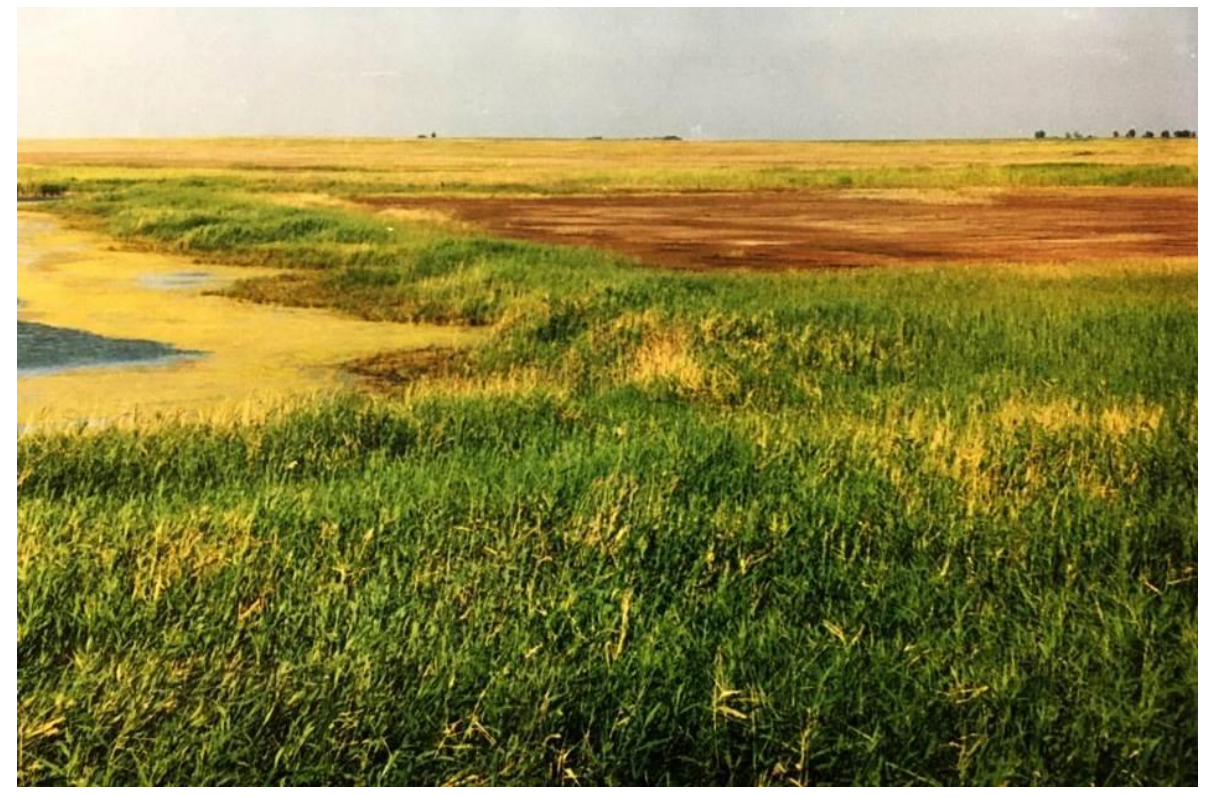

Рисунок 2. Сложная структура почвенного покрова: от засоленных и солонцеватых почв до лугово-черноземных солонцеватых. Юдинский плёс, оз. Чаны.

Освоение и внедрение в сельскохозяйственное производство земель со столь сложной ландшафтной мозаикой и почвенно-мелиоративными комплексами получило государственную поддержку в виде научного сопровождения проектов мелиорации. Согласно историографии мелиорации по Б.С. Маслову (2005), вслед за учреждением Убинской опытно-мелиоративной станции (УОМС), в Омском сельскохозяйственном институте в 1930 г. было сформировано «Бараббюро». Ученые Омского СХИ и УОМС вели исследования по гидрологии мелиорируемых земель, освоению засоленных почв и солонцов, тепловой мелиорации, продолжавшиеся вплоть до Великой Отечественной войны. В 1940 г. в Новосибирске создана проектная организация «Барабастройпроект» под руководством А.Д. Панадиади. С 1942 г. проводилось почвенно-мелиоративное обследование Кундранского займища площадью 30 тыс. га с целью его осушения. В феврале 1945 г. Совнарком СССР принял постановление «О мероприятиях по развитию животноводства и созданию кормовой базы в колхозах Барабинской степи Новосибирской области», предусматривающее, в том числе, активизацию мелиоративных работ. 
В апреле 1947 г. была создана Барабинская экспедиция, в составе которой для исследования процессов засоления почв в регионе направляется группа ученых Почвенного института им. В.В. Докучаева. Впервые почвы Барабы стали предметом глубоких исследований.

На основе обобщения материалов УОМС и Барабинской экспедиции в 1949 г. были опубликованы рекомендации ВНИИГиМ по мелиорации и освоению земель Барабы. В 1958 г. вышла книга «Мелиоративные мероприятия по Новосибирской области», где рассмотрен широких круг вопросов по осушению болот Барабинской низменности, Кулундинской степи и зоны Приобья, улучшению лугов и пастбищ на солонцах и при лиманном орошении. Обоснованы работы по влагонакоплению на пашне, снежной мелиорации, регулированию затопления пойм и орошения дождеванием, а также сельскохозяйственному водоснабжению и гидромелиорации, использованию торфяных ресурсов. Эти обобщенные рекомендации на основе локальных опытов не позволяли в полной мере оптимизировать почвенно-мелиоративные процессы, способствующие увеличению и сохранению плодородия почв, но тем не менее помогли значительно увеличить эффективность сельскохозяйственного производства.

Академик РАН Б.С. Маслов (2005) справедливо отметил, что осушение и освоение земель в 40-50 годы XX столетия проводилось экстенсивно, методом «проб и ошибок» из-за сравнительно низкого уровня культуры земледелия, однако все затраченные ресурсы себя оправдали. Но уже в то время было ясно, что для эффективного землепользования необходимы научно обоснованные технологии и мелиоративные мероприятия.

С майского (1966) Пленума ЦК КПСС и Постановления Советов Министров СССР от 2 октября 1972 г. «О дальнейшем усилении работ по мелиорации земель и улучшении использования орошаемых и осушенных земель» начался период активного возрождения и подъема мелиорации по всей стране и в Западной Сибири в частности. Правительство провозгласило лозунг: «В широком развитии мелиорации - будущее сельского хозяйства».

В 1967 г. начал свою производственную деятельность ФГУП «Западно-Сибирский государственный институт по проектированию водохозяйственного и мелиоративного строительства» (Запсибгипроводхоз). К решению научных проблем активно привлекали специалистов различных научных учреждений: Института почвоведения и агрохимии (ИПА) СО АН СССР (г. Новосибирск), институтов СО ВАСХНИЛ (р.п. Краснообск, Новосибирская обл.) и СибНИИГиМ Минводхоза СССР (г. Красноярск).

Согласно «Схеме районирования видов мелиорации по зонам РСФСР в целях повышения продуктивности земли и эффективного использования капитальных вложений», составленной Минводхозом РСФСР, на 01.11.1985 г. общий фонд земель, нуждающихся в гидромелиорациях, составлял 58,9 млн га, в том числе 52 млн га фонд регулярного орошения, 1,2 млн га - лиманного, 5,7 млн га - осушения. Мелиоративный фонд определялся, в основном, в границах сельскохозяйственных угодий. Половина фонда осушения размещалась в Западно-Сибирском экономическом районе, $20 \%$ - на территории Восточно-Сибирского и $12,5 \%$ - в Якутской АССР. По экономическим районам фонд орошения распределялся следующим образом: в ЗападноСибирском районе - 30\% земель, Уральском - 16\%, Восточно-Сибирском - $9 \%$.

Большая часть территорий лиманного орошения находилась в Западно-Сибирском экономическом районе и Якутской АССР. Площадь солонцов и солонцеватых почв, характеризующихся низким естественном плодородием и плохими физико-химическими свойствами, занимала в зоне деятельности Минводхоза РСФСР 14,2 млн га, ареал распространения таких сельхозугодий в Западной Сибири достигал 7 млн га. Значительные площади в Западной Сибири занимали кислые почвы - 2,7 млн га. Наиболее эффективным с экономической точки зрения видом мелиорации в Западно-Сибирском регионе признавали орошение.

Первое специализированное, методологически обоснованное научное сопровождение проекта мелиорации земель было разработано в 1973 г. для технико-экономического доклада по мелиоративным мероприятиям в Новосибирской области. Научными сотрудниками лаборатории мелиорации почв ИПА СО АН СССР и почвоведами ФГУП «Запсибгипроводхоз» (Х.Х. Мелеск, М.С. Фоминых, М.Т. Устинов, Н.Г. Тимофеева, под руководством и при непосредственном участии заведующего лаборатории мелиорации почв ИПА д.б.н. П.С. Панина) были составлены почвенно-мелиоративная карта и карта мелиоративных мероприятий (1:500 000). Основой для указанных карт послужила Почвенная карта Новосибирской области, изданная в 1963 г. в масштабе 1:400000 под редакцией д.с.-х.н. Р.В. Ковалева. Были разработаны комплексы мероприятий, вычислены площади земель, подлежащих мелиорации, и дано распределение мелиоративных категорий земель по области, объединены 
почвы однотипных ландшафтов, близких между собой по сельскохозяйственному достоинству и характеру необходимой мелиорации (Панин, Мелеск, 1978). Авторами охарактеризованы укрупнённые качественные единицы почвенного покрова, которые обозначили индексами: П зональные автоморфные пахотнопригодные почвы; С - почвы солонцеватых комплексов; К комплексы луговых, в разной степени засоленных и солонцеватых почв; Б - комплекс постоянно переувлажненных и заболоченных оторфованных почв и торфяников; Л - комплекс луговых, лугово-болотных и аллювиальных почв. Категории Л, Б, С и К составили основной мелиоративный фонд земель Новосибирской области (рис. 3).

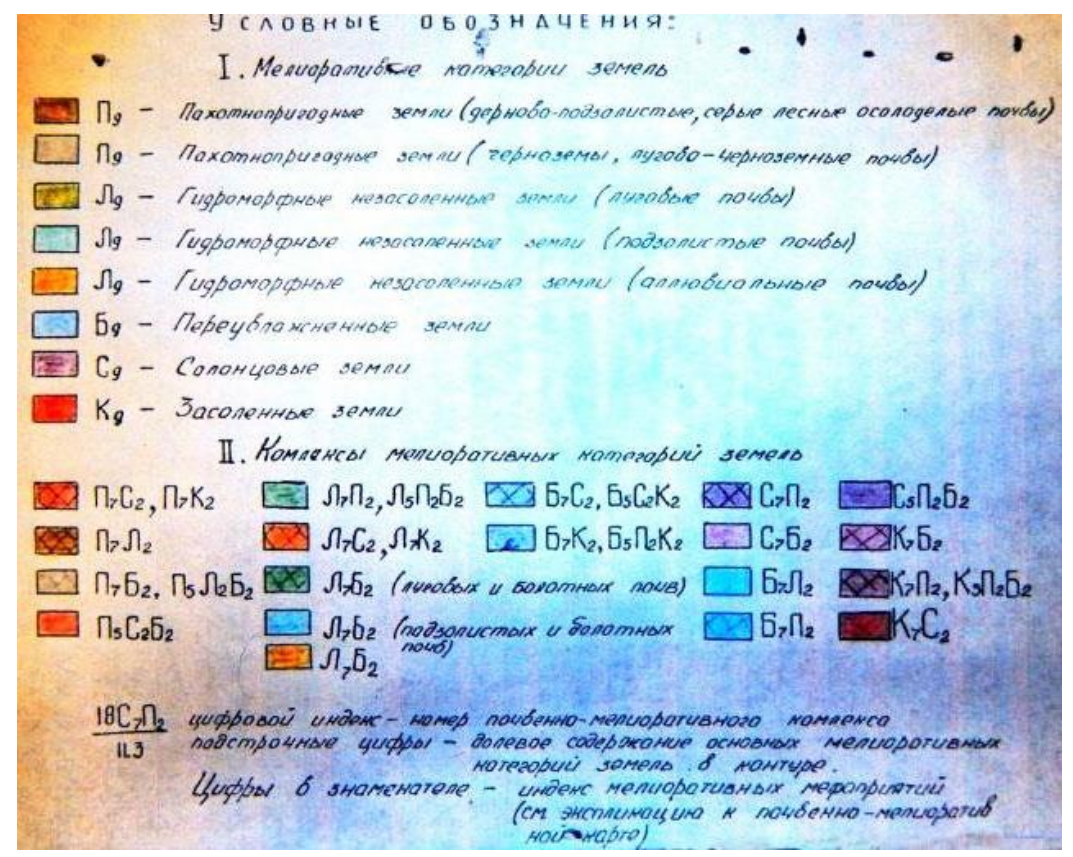

Рисунок 3. Условные обозначения почвенно-мелиоративных комплексов на карте, 1973 г.

В соответствии с крупными качественными единицами почвенного покрова на основе сложных ландшафтов, выраженных в категории, были рекомендованы схематичные мелиоративные мероприятия:

1 - сеть сбросных коллекторов по заболоченной равнине;

2 - регулируемое осушение;

3 - сброс временно избыточных поверхностных вод;

4 - комплекс мелиоративных мероприятий в речных долинах;

5 - земледелие без мелиорации почв;

6 - орошение пахотнопригодных земель;

7 - комплекс мелиоративных мероприятий в условиях гривноложбинного рельефа;

8 - регулируемое осушение засоленных переувлажненных земель;

9-12 - мелиорация солонцов;

13 - залужение увлажненных засоленных земель солеустойчивыми видами трав;

14 - территории, на которых мелиоративные мероприятия проводить экономически нецелесообразно.

Впервые была проведена научно обоснованная оценка почвенного покрова с учетом его мелиоративных особенностей для проекта-схемы мелиорации земель и водохозяйственного обустройства территории Новосибирской области на ближайшую и отдаленную перспективу (до 2000 г.). Выявленные мелиоративные особенности ландшафтов и их почвенного покрова в Новосибирской области стали основой для дальнейшей разработки методологических подходов в сфере научного сопровождения проектов мелиорации земель.

В 1979 - начале 1980 года для разработки основных положений «Технико-экономического обоснования (ТЭО) переброски части стока сибирских рек в бассейн Аральского моря» была проведена мелиоративная оценка природных условий, в том числе почвенного покрова Новосибирской и Кемеровской областей, составлены карта мелиоративных группировок (M 1: 500 000) и карта мелиоративных категорий. 
В основу работы положены методические рекомендации Почвенного института им. В.В. Докучаева, а именно «Легенда карты почвенно-мелиоративных группировок земель среднего региона в масштабе 1:1000000», разработанная для схематической оценки территории на нуждаемость в сельскохозяйственной мелиорации. Проект выполнен специалистами «Запсибгипроводхоз» совместно с сотрудниками ИПА СО АН СССР с учетом региональных особенностей почвенного покрова. В перечень наиболее значимых лимитирующих факторов, определяющих мелиоративные свойства почв, были включены дренированность, рельеф, засоление, солонцеватость, токсическая щелочность почв, переувлажнение, низкая водопроницаемость подстилающих пород. Комплексная оценка почв проведена с учетом гидрогеологических, инженерно-геологических, геоботанических, геоморфологических и других природных условий, что послужило новым этапом детализации мелиоративных особенностей почвенного покрова Западной Сибири.

На специальном Всесоюзном координационном совещании, проведенном 21-23 апреля 1981 г. в г. Пущино (Московская область) научным советом по проблемам почвоведения и мелиорации почв, была дана оценка изменения почвенно-мелиоративного состояния территорий в зоне влияния перераспределения стока. В работе совещания приняли участие 80 человек представители 23 организаций, в том числе ИПА СО АН СССР (П.С. Панин, В.П. Панфилов, И.Н. Угланов), «Запсибгипроводхоз» (М.Т. Устинов) и др. Были представлены доклады организацийисполнителей и доклад представителя научного совета по проблемам почвоведения и мелиорации почв, члена-корреспондента АН СССР В.А. Ковды.

По результатам обсуждений вынесено постановление: «Просить ... ИПА СО АН СССР совместно с соответствующими подразделениями Минводхоза СССР разработать программы проведения комплексных исследований на опытно-производственных участках. Считать обязательными элементами этой программы составление крупномасштабных гидрогеологических (M 1:50 000) и почвенно-мелиоративных (M 1:5000-1:10000) карт. Рекомендовать организациямисполнителям при изучении мелиоративного состояния территорий руководствоваться «Перечнем мелиоративных признаков почв для целей орошения и борьбы с засолением» и «Перечнем мелиоративных признаков свойств и процессов мерзлотных и длительно-сезонно-мерзлотных почв для целей осушения, орошения и освоения». По результатам проведенных изысканий проект не получил поддержки и постановлением Политбюро ЦК КПСС 1986 г. решено прекратить дальнейшие работы.

Вслед за «Проектом технико-экономического обоснования переброски части стока сибирских рек в бассейн Аральского моря, 1979», последовал не менее грандиозный проект - «Схема развития мелиорации и водного хозяйства СССР на период до 2000 г.», требующий усовершенствования методических подходов к изучению мелиоративного фонда земель, и в том числе детализации почвенно-мелиоративных исследований. С учетом этого, для выделения почвенно-мелиоративной группировки земель как в целом для СССР, так и для Новосибирской области в частности, предложена расчетная модель (Методические указания..., 1982). Разработанная модель предусматривала проведение почвенно-мелиоративной оценки по 5-балльной шкале отдельно по каждому свойству почвы, требующему улучшения. Сумма частных почвенно-мелиоративных оценок выявляла почвенномелиоративную группу, отражая суммарную оценку «трудоемкости» мелиоративного улучшения почв, независимо от того, какими конкретными свойствами она вызывается и обозначается общим почвенномелиоративным индексом.

В 1983 г. в тесном содружестве почвоведов «Запсибгипроводхоз» с сотрудниками ИПА СО АН СССР было разработано «Природно-мелиоративные районирование Новосибирской области с почвенномелиоративным обоснованием», которое было во многом схематично и в дальнейшем потребовало доработки (Гаджиев, Устинов, 2001).

На основе данных материалов 1982-1983 гг. Октябрьский Пленум ЦК КПСС (1984) включил проект «Увеличение водности реки Карасук и озера Чаны» в перечень первоочередных объектов мелиорации на XII пятилетку. Этому решению способствовали обширные натурные исследования региональных природно-мелиоративных условий, в том числе структуры почвенного покрова и, в частности, детального изучения местных черноземов. В развитие этого решения 11 февраля 1986 г. было принято Постановление Совета Министров СССР № 207 «О мерах по строительству объектов для подачи воды из реки Обь в реку Карасук и озеро Чаны», которым предусматривалось в 1987 г. закончить разработку проекта первой очереди строительства и начать его реализацию. Это был один из самых спорных, но и наиболее тщательно проработанных мелиоративных проектов. 
Южные районы Новосибирской области, тяготеющие к бассейну реки Карасук, характеризуются более интенсивным использованием сельскохозяйственных угодий, чем в целом по области. Так, удельный вес пашни в составе сельхозугодий в среднем по области составляет $32 \%$, а по южным районам доходит до $48 \%$. Вероятность засух в этих районах превышает $70 \%$. Стабилизация и дальнейшая интенсификация агропромышленного комплекса - основной отрасли народного хозяйства этой зоны - может быть произведена только в условиях достаточного увлажнения, которое может быть обеспечено только при условии использования оросительных мелиораций. Отсутствие в достаточном количестве местных источников поверхностных и подземных вод для развития орошения вызывает необходимость привлечения вод реки Обь. В соответствии с проектом «Увеличение водности реки Карасук...» на базе обской воды в бассейне реки Карасук и вдоль тракта водоподачи предлагалось оросить 63 тыс. га сельскохозяйственных угодий (1 очередь) (Проект ..., 1988), из них 70-80\% - черноземы (зона чернозёмных почв юговосточной части Обь-Иртышского междуречья (рис. 4).

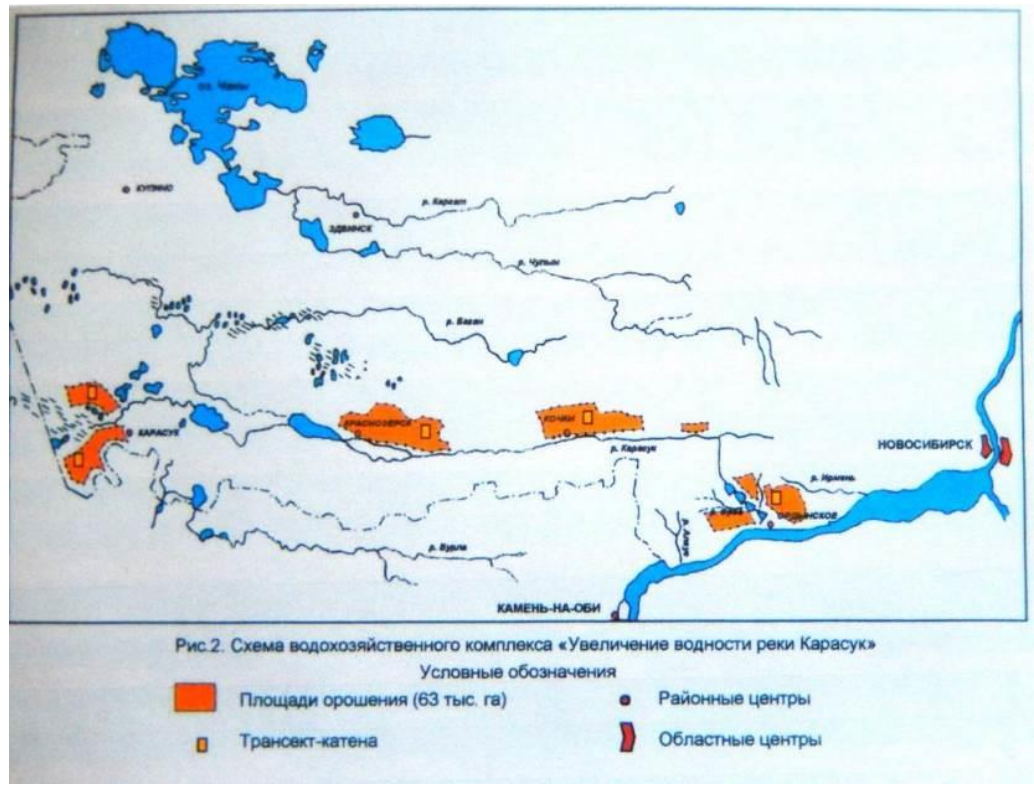

Рисунок 4. Схема водохозяйственного комплекса «Увеличение водности реки Карасук».

В процессе обсуждения проекта «Обосновывающие материалы увеличения водности реки Карасук» в научном сообществе развернулась оживленная дискуссия о негативном влиянии орошения на черноземы. Поэтому для обсуждения центрального звена в проекте - вопроса возможности и целесообразности орошения черноземов Западной Сибири - 17 марта 1983 г. было проведено специальное совещание Президиума СО АН СССР под председательством академика В.А. Коптюга, на заседании которого с докладом выступил директор ИПА СО АН СССР профессор Р.В. Ковалев. По результатам заседания Министру мелиорации и водного хозяйства СССР Н.Ф. Васильеву были направлены предложения по использованию западносибирских черноземов как объекта орошения, заверенные председателем СО АН СССР академиком В.А. Коптюгом и председателем СО ВАСХНИЛ академиком П.Л. Гончаровым (рис. 5), в которых было дано детальное обоснование их орошения. В этих предложениях были учтены масштабы проектирования строительства и ввода в эксплуатацию оросительных систем на территории Западно-Сибирской равнины; было предложено уделить особое внимание разработке новых и усовершенствованию известных способов рационального использования и охраны черноземов на фоне орошения. Было отмечено, что широкое применение оросительных мелиораций черноземов в европейской части Советского Союза привело к резкому ухудшению их свойств и снижению плодородия. Поэтому следует особое внимание уделять негативным процессам, возникающим в результате орошения черноземов Западной Сибири, отличающихся от европейских аналогов значительно худшими агромелиоративными качествами. Необходимо четко разграничивать внутризональные особенности современного агромелиоративного состояния сибирских черноземов, оценить характер возможных изменений их свойств при широком вовлечении в орошаемое земледелие. Неоднородность почвенно-мелиоративных условий черноземной зоны Сибири диктует 
необходимость дифференцированного подхода к использованию черноземов как объекта орошения. На севере Кулундинской и Прииртышской равнинах для организации интенсивного кормопроизводства целесообразно регулярное, строго нормированное орошение отдельных массивов черноземов, имеющих легких механический состав и достаточную естественную дренированность. На Приобском плато целесообразно регулярное орошение отдельных дренированных массивов черноземов для выращивания кормовых и овощных культур. В целях борьбы с ирригационной эрозией необходимо строгое соблюдение поливных норм и режимов орошения. Среди прочего предлагалось продолжить глубокие экспериментальные и теоретические исследования черноземов Западной Сибири на фоне орошения и создать для этого 1-2 опытноэкспериментальных стационара в каждой из указанных зон, а также 2-3 экспериментальные оросительные системы.

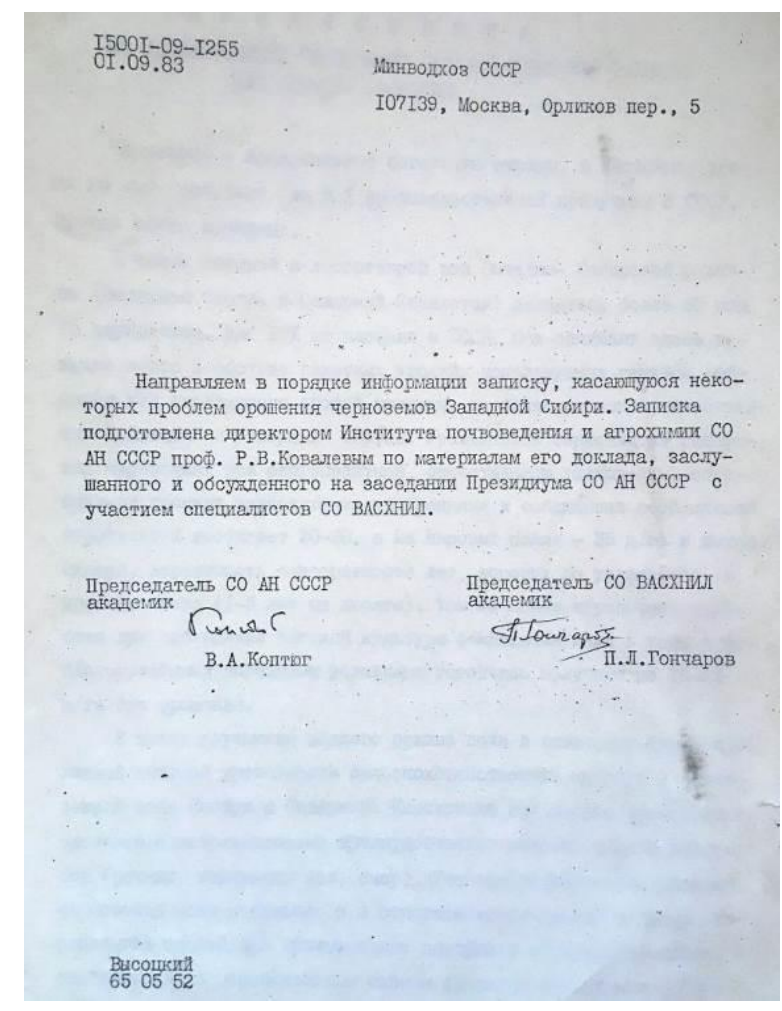

Рисунок 5. Записка «Предложения по использованию черноземов Западно-Сибирской равнины как объектов орошения»

Чтобы разрешить противоречия и выработать стратегию по совершенствованию научных основ земледелия с учетом зональных свойств и режимов почв, в г. Одессе 8-13 сентября 1983 г. было проведено Всесоюзное совещание «Плодородие черноземов в связи с интенсификацией их использования». От ИПА СО АН СССР участвовали В.П. Панфилов, Г.Ф. Копосов, Т.Ф. Зайцева, А.М. Шкаруба, от «Запсибгипроводхоз» М.Т. Устинов. Основополагающие решения данного совещания: на южных черноземах Украины, Поволжья, Казахстана и Западной Сибири, где недостаток продуктивной влаги наиболее высокий и имеются природные запасы воды хорошего качества, систематическое орошение остается одним из основных средств, обеспечивающих компенсацию дефицита почвенной влаги и получения стабильных урожаев, особенно кормовых культур. Вызывает тревогу использование для полива черноземов щелочных и нейтральных слабоминерализованных вод (1-3 г/л с повышенным содержанием сульфатов и хлоридов натрия). Под влиянием этих вод химические и физические свойства почв изменялись в сторону осолонцевания, ощелачивания, дезинтеграции структуры, потери обменного кальция и запасов гумуса и формированию признаков осолоделого солонца».

Несмотря на обширную отечественную и зарубежную литературу по оценке качества поливной воды и влиянию вод различного состава на плодородие почв и продуктивность растений, не было выработано единое мнение по этим вопросам и единый принцип оценки качества поливной воды. Это объясняется прежде всего отсутствием комплексной почвенно- 
мелиоративной оценки пригодности воды для орошения. Возможность применения оросительных мелиораций необходимо рассматривать по комплексу следующих показателей: химическому составу оросительных вод, солеустойчивости сельскохозяйственных культур, свойствам и режимам почв, мелиоративному состоянию орошаемых земель, а также имеющейся техники и используемой технологии орошения.

Почвенному институту им. В.В. Докучаева (головная организация) и Институту почвоведения и агрохимии СО АН СССР было поручено в срок до 1 января 1987 г. «завершить разработку комплексной программы исследований по рациональному использованию орошаемых и неорошаемых черноземов, повышению их плодородия в условиях интенсивного использования».

Для обоснования и успешной реализации перспективных планов и проектов орошения, широкого внедрения ирригации в специфичном по природно-климатическим условиям регионе Западной Сибири, Институтом почвоведения и агрохимии СО АН CССР при участии специалистов «Запсибгипроводхоз» были проведены исследования региональных особенностей генетических и мелиоративных свойств сибирских черноземов и характера их изменения при орошении, на основании которых издана монография «Черноземы: свойства и особенности орошения» (1988). В монографии обобщены новые материалы глубокопрофильного изучения свойств, режимов и плодородия сибирских черноземов при орошении, способствующие решению проблем их ирригационного освоения, рационального использования и охраны.

Из-за широкого распространения в Западно-Сибирском регионе солонцов и солонцовых почв (6948 тыс. га), а также их залегания пятнами в массивах зональных плодородных земель встала проблема рационального использования солонцовых комплексов в сельскохозяйственном производстве. Обладающие неблагоприятными физическими и химическими свойствами, но при этом высоким потенциальным плодородием, солонцы стали объектом обсуждений на специальном Всесоюзном научно-техническом совещании «Пути повышения продуктивности солонцовых земель» в г. Новосибирске (ВАСХНИЛ) 30.06-04.07 1986 г. На совещании были предложены пути повышения эффективности мелиоративного освоения солонцовых территорий (Д.С. Булгаков), оценено современное состояние проблем классификации, географии и картографирования солонцовых почв (Э.А. Корнблюм), периодичность развития солонцов (П.С. Панин), особенности мелиорации и освоения солонцов в условиях орошения. Для участников совещания провели экскурсию в совхоз «Кабинетный» Чулымского района Новосибирской области для ознакомления с опытом мелиорации корковых солонцов различными дозами гипса (рис. 6). Следует сказать, что на этом опытном участке наблюдения за уровнем и химическим составом грунтовых вод и их влиянием на свойства почв ведутся исследователями СФНЦА РАН и ИПА СО РАН на протяжении уже более 30 лет (Елизаров и др., 2020).

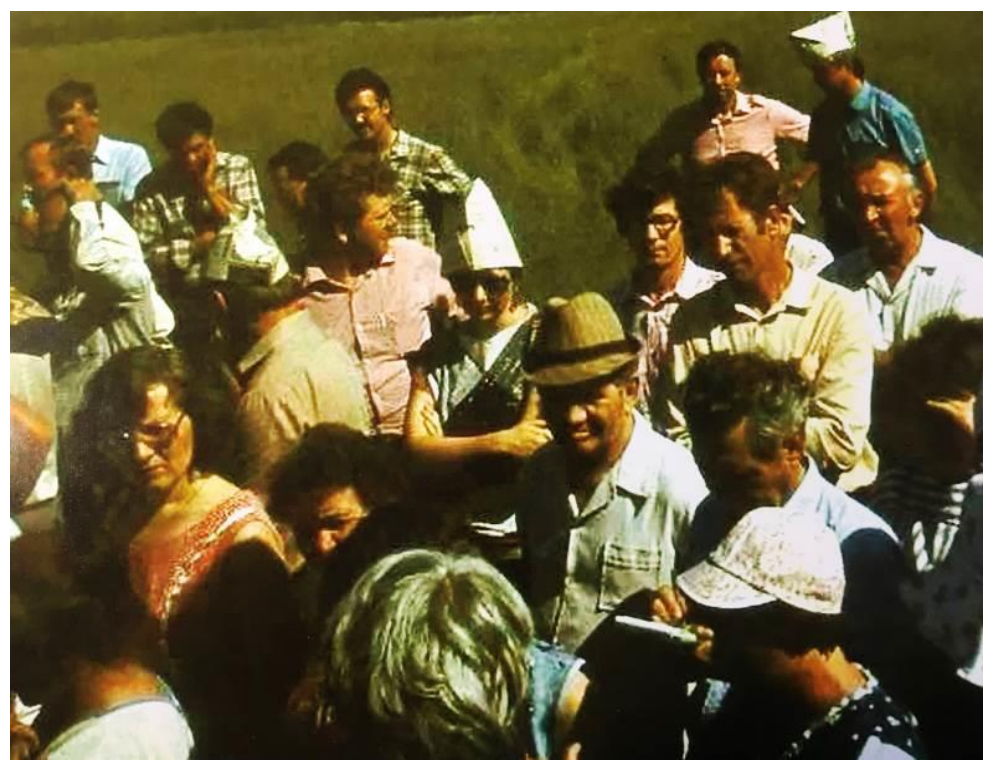

Рисунок 6. П.С. Панин (в центре) и участники Всесоюзного научно-технического совещания на экскурсии в совхозе «Кабинетный», Новосибирская область, 1986 г. 
В соответствии с заданием комитета по земельным ресурсам Новосибирской области в 1994 г. была составлена эколого-мелиоративная карта левобережной части Новосибирской области масштаба 1:500 000. Авторы карты: В.А. Казанцев, Л.А. Магаева, Т.Н. Елизарова (ИПА СО РАН), М.Т. Устинов («Запсибгипроводхоз»), под общей редакцией В.Н. Михайличенко (ИПА СО РАН); также в составление карты принимали участие Г.П. Тарасов, В.Н. Васькина (Новосибирская геолого-поисковая экспедиция) и А.И. Кожевников (СибНИИЗХиМ).

Основой для составления карты послужил большой фактический материал, полученный при производстве целевых почвенных, геологических, гидрогеологических и других съемок крупного и среднего масштаба. При эколого-мелиоративной оценке почвенного покрова территории, а также ландшафтной почвенной характеристике, был применен геосистемный подход (Казанцев и др., 2001). Т.Н. Елизаровой с соавторами в монографии «Эколого-мелиоративный потенциал почвенного покрова Западной Сибири» (1999) предложены критерии его оценки. Экологомелиоративный потенциал должен отражать интегральную характеристику объектов, не только пространственную совокупность природных систем, но и вертикальную стратификацию компонентов на глубину, соответствующую их рангу. Для этого целесообразно рассматривать систему почвы - породы зоны аэрации - грунтовые и артезианские воды, учитывая особенности климата и растительности. Такой системный подход позволил развить совершенно новое направление природопользования - экологическую мелиорацию, учитывающую экологическую оценку современного состояния природных систем и определяющую оптимальный вариант мелиорации исследуемых почв. В 2000 г. для Атласа Новосибирской области (второе издание, 2002) специалистами ИПА СО РАН В.А. Казанцевым, Т.Н. Елизаровой, Л.А. Магаевой и М.Т. Устиновым с использованием комплексного ландшафтного подхода была составлена карта «Мелиорации почв» масштаба 1:400000, где выделены 22 района по основным мелиоративным мероприятиям, рекомендуемым для рационального землепользования.

По инициативе Минсельхоза СССР и Россельхозакадемии в 1995 г. в г. Новосибирске была проведена научно-практическая конференция, посвященная 100-летию начала государственных работ по обводнению и осушению земель Барабинской низменности под руководством одного из основоположников российской мелиорации - И.И. Жилинского. Участниками конференции подведены итоги столетнего опыта мелиоративных работ в Западной Сибири и отмечена их высокая эффективность. От ИПА СО РАН участвовали: В.К. Бахнов, Т.Н. Елизарова, В.А. Казанцев, А.И. Сысо, А.А. Сеньков, Л.А. Магаева, М.Т. Устинов (рис. 7).

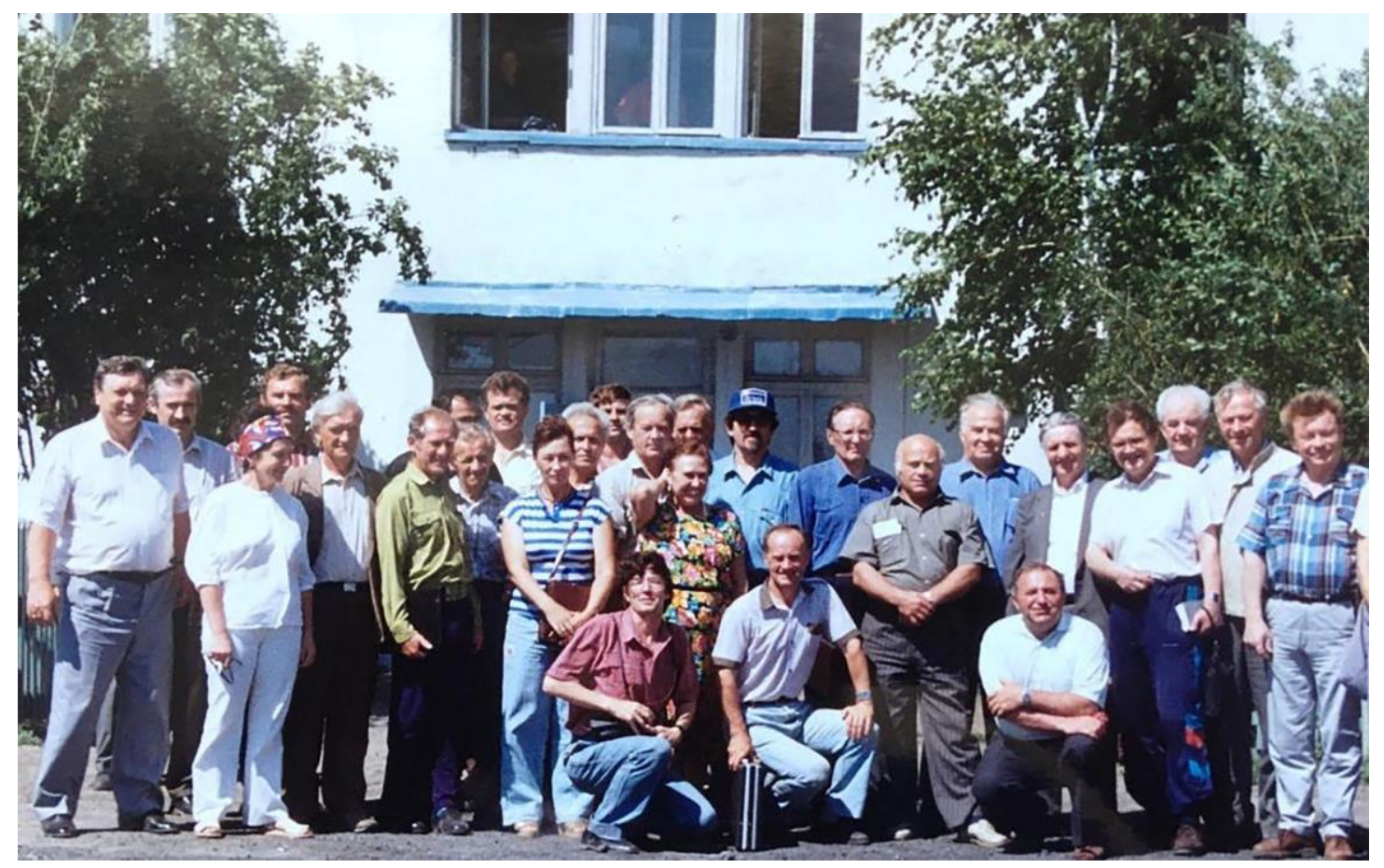

Рисунок 7. Участники научно-практической конференции, посвящённой 100-летию создания экспедиции И.И. Жилинского по обводнению и осушению земель Западной Сибири.

Убинская ОМС, 1995 г. 
В последнее время региональные научно-практические форумы по комплексу проблем и их решению в сфере мелиорации земель, связанных с рациональным использованием и охраной природных ресурсов в Новосибирской области, проводятся достаточно регулярно (рис. 8). Основная цель форумов - возрождение, сохранение и развитие мелиоративного дела в Сибири. Материалы форумов и их резолюции опубликованы в журнале «Мелиорация и водное хозяйство».

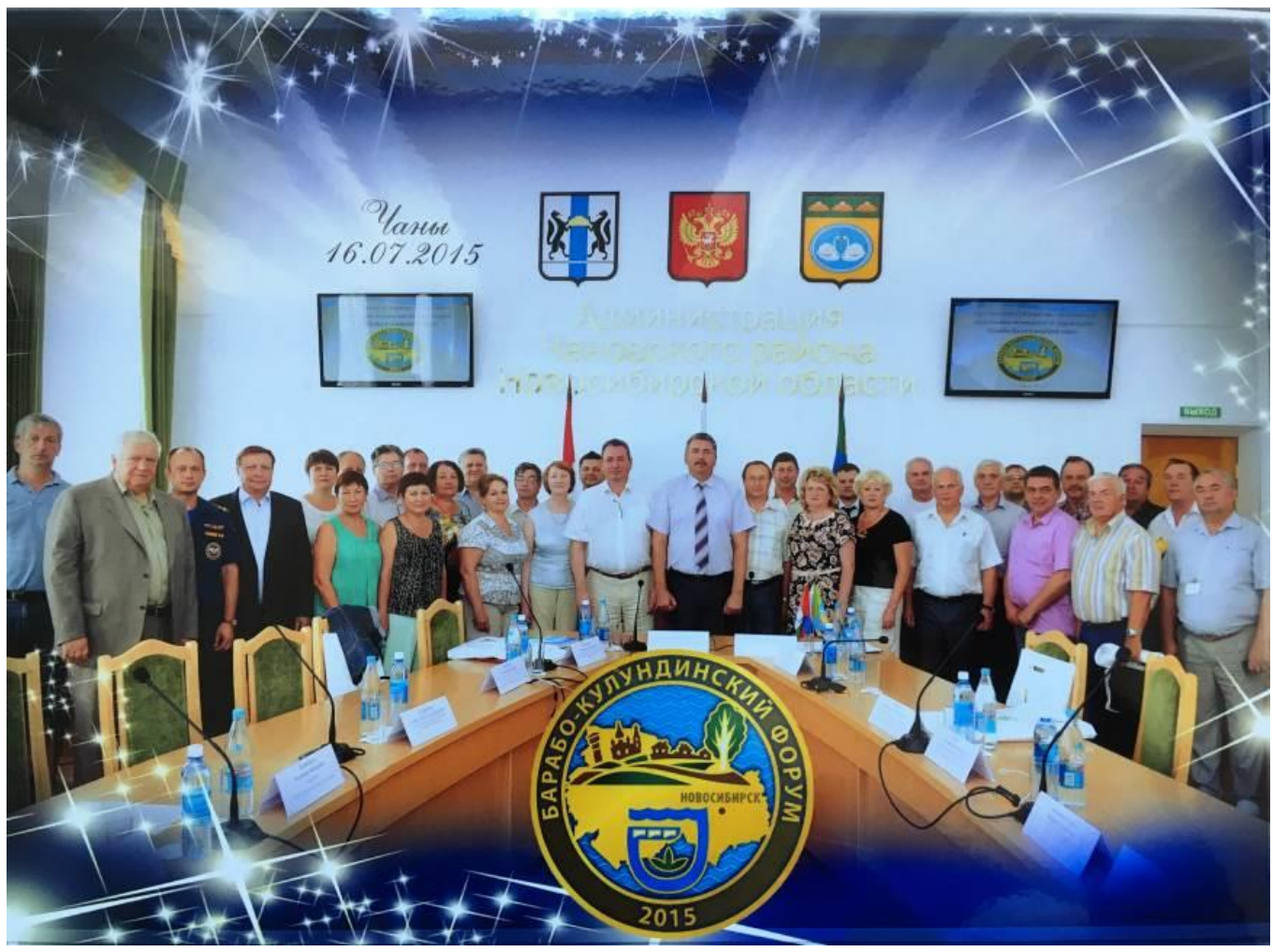

Рисунок 8. Участники Барабо-Кулундинского форума, р. п. Чаны, Новосибирская область, 2015 г.

Примером научного сопровождения проектов мелиорации стала монография «Экологоэкономическая эффективность комплексных мелиораций Барабинской низменности» (2009). В данной монографии авторами в свете решения научно-практической конференции от 5-8 июля 2005 г., посвященной 110-летию мелиоративных работ в Барабинской низменности, выполнен анализ современного природно-мелиоративного состояния земель и социально-хозяйственных условий Барабинской низменности; с учетом нового подхода обоснованы мелиоративные мероприятия, позволяющие повысить эколого-экономический потенциал региона. Применение новых научных направлений, базирующихся на использовании энергетических подходов к оценке мелиоративной деятельности в сочетании с принципами адаптивно-ландшафтного земледелия, позволило разработать технологию формирования продуктивного и экологически устойчивого агроландшафта, которая включает:

- оценку энергетического состояния природного объекта;

- расчет продуктивного потенциала и экологически допустимой величины урожайности сельскохозяйственных культур для конкретных природных условий;

- обоснование видов и объемов мелиорации на основе энергетических и экологических критериев;

- оптимизацию соотношения элементов агроландшафта с использованием ГИС-технологий;

- проектирование природных мероприятий, обеспечивающих компенсацию антропогенной деятельности;

- эколого-экономическое обоснование предложенного комплекса мелиоративных мероприятий.

Расчеты, базирующиеся на анализе обширного фактического материала ФГУП «Запсибгипроводхоз», данных Департамента АПК Новосибирской области, материалов научных публикаций по Барабинской низменности, научных исследований ученых ВНИИГиМ, а также комплексной экспедиции ВНИИГиМ - ФГУП «Запсибгипроводхоз» показали: 
- современное состояние сельскохозяйственных угодий Барабинской низменности трудно назвать удовлетворительным. Продуктивность сельскохозяйственных угодий низкая, составляющая 0,4-0,7 тыс. к. ед./га на основных почвах и 0,9 тыс. к. ед/га на чернозёмах выщелоченных и обыкновенных. Почвы бедны питательными элементами, деградируют, воспроизводство почвенного плодородия не происходит, экологическая и энергетическая устойчивость крайне низкая;

- проведение только гидротехнических мелиораций позволит увеличить продуктивность сельскохозяйственных угодий до 1,1-4,3 тыс. к. ед./га, но при этом не будут соблюдаться экологические требования: коэффициент устойчивости агроландшафта не превысит 0,5, баланс гумуса будет отрицательным;

- реализация агротехнических и культурно-технических мероприятий в комплексе с химической и агробиомелиорацией не позволит достичь экологически обоснованного величины продуктивности, но обеспечит положительный баланс гумуса за счет агротехнических мероприятий, при этом устойчивость территории (Барабинской низменности) останется низкой $($ Ку $=0,1-0,35)$;

- при проведении комплекса мелиоративных и агротехнических мероприятий возможно увеличение продукционного потенциала обрабатываемых угодий до экологически обоснованной величины, равной 3,0-4,8 тыс. к. ед./га, при поддержании коэффициента устойчивости на уровне $0,84-0,98$ и положительном балансе гумуса.

Рекомендуемый адекватный комплекс первоочередных мелиоративных и агротехнических мероприятий должен включать: реконструкцию осушительных систем, реконструкцию систем лиманного орошения и строительство новых оросительных систем с проведением агромелиоративных мероприятий и культурно-технических работ.

Реализация проекта по развитию комплексных мелиорационных мероприятий на территории Барабинской низменности является экономически обоснованной: срок окупаемости проекта находится в пределах 5 лет.

Следует подчеркнуть, что Постановлением Правительства РФ о 30 марта 2017 г. №396 «О внесении изменений в Государственную программу развития сельского хозяйства и регулирования рынков сельхозпродукции, сырья и продовольствия на 2013-2020 годы» установлены следующие задачи:

- повышение продуктивности потенциала мелиорируемых земель и эффективное использование природных ресурсов;

- повышение плодородия почв средствами комплексной мелиорации в условиях изменения климата.

В этой связи несомненно актуальным является широко обсуждаемый вопрос о создании Сибирского филиала Российского научно-исследовательского института проблем мелиорации в г. Новосибирске для научного обеспечения мелиорации земель в Сибирском Федеральном округе.

\section{ФИНАНСОВАЯ ПОДДЕРЖКА}

Работа выполнена по государственному заданию ИПА СО РАН при финансовой поддержке Министерства науки и высшего образования Российской Федерации.

\section{ЛИТЕРАТУРА}

1. Атлас Новосибирской области. ФГУП «Новосибирская картографическая фабрика». Роскартография, 2002.

2. Гаджиев И.М., Устинов М.Т. Почвенно-мелиоративная группировка минеральных земель юга Западной Сибири // Сибирский экологический журнал. 2001. Том 8. № 3. С. 293-298.

3. Елизарова Т.Н., Казанцев В.А., Магаева Л.А., Устинов М.Т. Эколого-мелиоративный потенциал почвенного покрова Западной Сибири. Новосибирск: Наука, Сибирская издательская фирма РАН, 1999. 240 c.

4. Елизаров Н.В., Попов В.В., Семендяева Н.В. Современный гидроморфизм солонцов лесостепной зоны Западной Сибири // Почвоведение. 2020. № 12. С. 1451-1459. DOI: 10.31857/S0032180X20120059

5. Казанцев В.А., Магаева Л.А., Елизарова Т.Н., Устинов М.Т. Эколого-мелиоративная оценка почвенного покрова южной лесостепи Барабинской равнины // Сибирский экологический журнал. 2001. Том 8. № 3. С. $275-280$. 
6. Кирейчева Л.В., Белова И.В., Глистин М.В., Устинов М.Е., Юрченко И.Ф. Эколого-экономическая эффективность комплексных мелиораџий Барабинской низменности. М.: ВНИИЛ. 2009. 312 с.

7. Маслов Б.С. Комплексная мелиорация Барабинской низменности и ее научное сопровождение // Мелиорация и водное хозяйство. 2005. № 6. С.11-16.

8. Маслов Б.С. Первый опыт мелиорации болот в Барабинской низменности // Сельские новости. 2005 . № 4. C. $9-11$.

9. Методические указания по определению мелиоративного фонда. Почвенно-мелиоративное обоснование. М.: Союзгипроводхоз, 1982.

10. Панин П.С., Мелеск Х.Х. Почвенный покров и районирование мелиоративных мероприятий // Новосибирская область. Природа и ресурсы. Новосибирск: Наука Сибирское отделение, 1978. 125-147 с.

11. Проект «Увеличение водности p. Карасук (1 очередь). Новосибирская область». Конспект «Запсибгипроводхоз», г. Новосибирск, 1988.

12. Черноземы: свойства и особенности орошения. Новосибирск: Наука Сибирское отделение, 1988.256 с.

Поступила в редакциию 24.06.2021

Принята 30.06.2021

Опубликована 05.11.2021

\title{
Сведения об авторах:
}

Устинов Михаил Тимофеевич - кандидат биологических наук, старший научный сотрудник лаборатории географии и генезиса почв ФГБУН Институт почвоведения и агрохимии CO РАН (г. Новосибирск, Россия); ustinov@issa-siberia.ru

Гаврилов Денис Александрович - кандидат биологических наук, старший научный сотрудник лаборатории географии и генезиса почв ФГБУН Институт почвоведения и агрохимии CO РАН (г. Новосибирск, Россия); gavrilov@issa-siberia.ru

Елизаров Николай Владимирович - кандидат биологических наук, старший научный сотрудник лаборатории географии и генезиса почв ФГБУН Институт почвоведения и агрохимии СО РАН (г. Новосибирск, Россия); elizarov@issa-siberia.ru

Авторы прочитали и одобрили окончательный вариант рукописи.

(c) ЕҮ

\section{HISTORICAL ASPECTS OF LAND MELIORATION DEVELOPMENT IN WEST SIBERIA}

\author{
(c) 2021 M.T. Ustinov, D.A. Gavrilov ${ }^{(\mathbb{D})}$, N.V. Elizarov
}

Institute of Soil Science and Agrochemistry of the Siberian Branch of the Russian Academy of Sciences, Novosibirsk, Russia.E-mail: ustinov@issa-siberia.ru

The article presents a historical review of scientific and practical materials about the development of soil melioration projects in West Siberia, emphasizing the need for their comprehensive research support. The article describes the methodology and means for studying and implementing land melioration projects developed by researchers in various fields, representing combined efforts of Institute of Soil Science and Agrochemistry of the Siberian Branch of the USSR Academy of Sciences, V.V. Dokuchaev Soil Science Institute and A.N. Kostyakov Russian Research Institute of Hydrological Engineering and Melioration.

Key words: land melioration; chernozems; irrigation; West Siberia; soil reclamation map; transfer of Siberian rivers; research methodology for melioration

How to cite: Ustinov M.T., Gavrilov D.A., Elizarov N.V. Historical aspects of land melioration development in West Siberia // The Journal of Soils and Environment. 2021. 4(2). e143. doi: 10.31251/pos.v4i2.143 (in Russian with English abstract)

\section{REFERENCES}

1. Atlas of the Novosibirsk region. Novosibirsk Cartographic Factory. Roskartografiya, 2002. (in Russian)

2. Gadzhiev I.M., Ustinov M.T. Soil-reclamation grouping of mineral lands in the south of Western Siberia, Siberian ecological journal, 2001, V. 8, No. 3, p. 293-298. (in Russian) 
3. Elizarova T.N., Kazantsev V.A., Magaeva L.A., Ustinov M.T. Ecological and reclamation potential of the soil cover in Western Siberia. Novosibirsk: Nauka Publ. SB RAS, 1999. 240 p. (in Russian)

4. Elizarov N.V., Popov V.V., Semendyaeva N.V. Modern hydromorphism of solonetzes in the forest-steppe zone of Western Siberia, Eurasian Soil Science, 2020, V. 53, No. 12, p. 1701-1708. DOI: 10.1134/S1064229320120054

5. Kazantsev V.A., Magaeva L.A., Elizarova T.N., Ustinov M.T. Ecological and reclamation assessment of the soil cover of the southern forest-steppe of the Barabinsk plain, Siberian ecological journal, 2001, V. 8, No. 3, p. 275280. (in Russian)

6. Kireicheva L.V., Belova I.V., Glistin M.V., Ustinov M.E., Yurchenko I.F. Ecological and economic efficiency of complex reclamation of the Baraba lowland. M.: VNIIL, 2009. 312 p. (in Russian)

7. Maslov B.S. Complex reclamation of the Baraba lowland and its scientific support, Melioration and water economy, 2005, No. 6, p. 11-16. (in Russian)

8. Maslov B.S. The first experience in reclamation of bogs in the Barabinsk lowland, Sel'skie novosti, 2005, No. 4, p. 9-11. (in Russian)

9. Methodical instructions for determining the reclamation fund. Soil-reclamation substantiation. M.: Soyuzgiprovodkhoz, 1982. (in Russian)

10. Panin P. S., Melesk H. Kh. Soil cover and zoning of reclamation measures. Novosibirsk region. Nature and resources. Novosibirsk: Nauka Publ. SB RAS, 1978. 125-147 p. (in Russian)

11. The project "Increasing the water content of the $r$. Karasuk (1st stage). Novosibirsk region". Synopsis "Zapsibgiprovodkhoz", Novosibirsk, 1988. (in Russian)

12. Chernozems: properties and features of irrigation. Novosibirsk: Nauka Publ. SB RAS, 1988. 256 p. (in Russian)

Received 24 June 2021

Accepted 30.06.2021

Published 05.11.2021

About the authors:

Ustinov Mikhail T. - Candidate of Biological Sciences, Senior Researcher in the Laboratory of Geography and Soil Genesis in the Institute of Soil Science and Agrochemistry of the Siberian Branch of the Russian Academy of Sciences (Novosibirsk, Russia); ustinov@issa-siberria.ru

Gavrilov Denis A. - Candidate of Biological Sciences, Senior Researcher in the Laboratory of Geography and Soil Genesis in the Institute of Soil Science and Agrochemistry of the Siberian Branch of the Russian Academy of Sciences (Novosibirsk, Russia); gavrilov@issa-siberria.ru

Elizarov Nikolay V. - Candidate of Biological Sciences, Senior Researcher in the Laboratory of Geography and Soil Genesis in the Institute of Soil Science and Agrochemistry of the Siberian Branch of the Russian Academy of Sciences (Novosibirsk, Russia); elizarov@issa-siberria.ru

The authors read and approved the final manuscript

(cc) EY The article is available under Creative Commons Attribution 4.0 License 